\title{
Influence of Genetic Polymorphisms on Bone Disease of Preterm Infants
}

\author{
SIMONE FUNKE, ÉVA MORAVA, MÁRTA CZAKÓ, GABRIELLA VIDA, TIBOR ERTL, AND GYÖRGY KOSZTOLÁNYI
}

Department of Obstetrics and Gynecology [S.F., G.V., T.E.], Medical School, University of Pécs, 7624 Pécs, Hungary; Department of Medical Genetics and Child Development [É.M., G.K.], University of Pécs, 7623 Pécs, Hungary; MTA-PTE Clinical Research Group

[M.C., G.K.], 7623 Pécs, Hungary

\begin{abstract}
Bone disease is an important complication among very low birth weight (VLBW, $<1500 \mathrm{~g}$ ) infants. In adults, osteoporosis is associated with polymorphisms of vitamin $\mathrm{D}$ receptor (VDR), estrogen receptor (ER), and collagen I $\alpha 1$ (COLIA1) genes. However, limited information is available regarding the role of these polymorphisms in bone disease in premature infants. We have investigated the possible association between bone disease and the allelic polymorphisms of these three genes in 65 VLBW infants. Twenty infants $(30.8 \%)$ were diagnosed with bone disease based on high activity of bone formation (serum alkaline phosphatase and osteocalcin), bone resorption (urinary excretion of calcium and pyridinium crosslink) markers, and positive radiologic signs. Statistically significant correlation between thymine-adenine repeat $\left[(\mathrm{TA})_{n}\right]$ allelic variant of ER gene and bone disease was observed. Infants without bone disorder more often carried a high number of repeats [(TA $)_{\mathrm{n}}>18$ ] [ odds ratio (OR): $0.17,95 \%$ confidence interval $(\mathrm{CI})$ : $0.05-0.55]$. A low number of repeats $\left[(\mathrm{TA})_{\mathrm{n}}<19\right]$ was found more frequently in infants suffering from bone disease (OR: $6.00,95 \% \mathrm{CI}$ : 1.77-20.31). Significant interaction $(p=0.009)$ between VDR and COLIA1 genotypes was observed. In a logistic regression model, bone disorder of preterms significantly correlated with male gender $(p=0.002)$, lower gestational age $(p=0.015)$, homozygous allelic variants of high number of (TA $)_{\mathrm{n}}$ repeats $(p=0.006)$, and interaction between VDR and COLIA1 genotype $(p=0.009)$. (Pediatr Res 60: 607-612, 2006)
\end{abstract}

$\mathrm{T}$ echnical advances and novel treatment modalities in the care of VLBW infants have increased their chance of survival and created new medical diseases such as the bone disease of preterm infants (1). The definition and name of the disorder affecting bones in premature infants is not clear. Since several pathophysiological conditions may be the cause for the same clinical picture, the nonspecific term "bone disease of premature infants" was suggested $(1,2)$. The forms of bone disease include osteomalacia (when the incorporation of minerals into the organic bone matrix is disturbed), osteopenia (decreased amount of bone tissue without radiologic signs and the sign of rickets), and osteoporosis (in pediatrics, history of fractures after minor trauma) (2). Factors contributing to diminished synthesis or increased resorption of or-

Received February 1, 2006; accepted July 4, 2006.

Correspondence: Simone Funke, M.D., Department of Obstetrics and Gynecology, Medical School, University of Pécs, 7624 Pécs, Édesanyák útja 17., Hungary; e-mail: simone.funke@aok.pte.hu

DOI: 10.1203/01.pdr.0000242340.45676.5d ganic bone matrix include inadequate calcium and phosphorus supply, severe systemic disease (e.g. bronchopulmonary dysplasia), side effects of drugs (corticosteroid, diuretics, methylxanthines), and lack of mechanical stimulation $(1,3)$. Recently, maternal parity and gender have been described as risk factors for bone disease in preterm infants (4).

Osteoporosis is a multifactorial skeletal disorder characterized by low bone mass and microarchitectural deterioration of bone tissue occurring due to different environmental, hormonal, nutritional, and genetic factors. Adult twin studies suggested that up to $75 \%$ of the variance in bone mass density (BMD) is genetically determined (5). In adults, association has been found between certain genetic polymorphisms (VDR, ER, and COLIA1) and the occurrence of osteoporosis (6-8). Few studies have addressed possible interactions among the different osteoporosis candidate genes $(9,10)$. To date, only one study has considered the genetic predisposition to bone mass content (BMC) in premature infants. It was suggested that multiple genes may be involved in the regulation of bone mass during childhood (11).

We performed a pilot study to analyze the possible association between bone disease in VLBW infants and the three main candidate genes for osteoporosis. Furthermore, an attempt was made to identify fetal and maternal risk factors for developing bone disease, such as gestational age, birth weight, height, gender, CRIB score, Apgar score, maternal parity, and length of hospitalization.

\section{METHODS}

Patients. This study included preterm infants with body weight below $1500 \mathrm{~g}$ who were born at gestational age $\leq 31 \mathrm{wk}$ at the Department of Obstetrics and Gynecology, Medical School, University of Pécs, and admitted to our neonatal intensive care unit between February 2002 and March 2004. Written consent was obtained from the parents. Sixty-five infants were enrolled, and 69 were excluded: 16 infants were excluded because they required surgery for a condition unrelated to bone disease, 8 infants because of major congenital abnormalities, 20 infants because they died in the first month of life, and 25 infants because of denial of parental consent. The 65 infants enrolled to our study had mean ( \pm SEM) birth weight $1113 \pm 29 \mathrm{~g}$ and gestational age $29 \pm 0.3 \mathrm{wk} ; 30$ were girls and 35 were boys. Gestational age 
was determined from the mother's last menstrual period or ultrasound examination during pregnancy and confirmed by the new Ballard examination (12).

Based on laboratory and radiologic findings, we divided the infants into two groups: infants with and without bone disease.

With regard to the duration of assisted ventilation and supplemental oxygen therapy, we did not find any significant difference between the two groups. The mean duration of assisted ventilation was $4.8 \mathrm{~d}$ in the group with bone disease and $4.0 \mathrm{~d}$ in the group without bone disease. The mean duration of oxygen supplementation was $14 \mathrm{~d}$ in the bone disease group and $12 \mathrm{~d}$ in the comparison group. Three infants in the bone disease group and two in the comparison group received steroid therapy $(0.5 \mathrm{mg} / \mathrm{kg} / \mathrm{d}$ for $10 \mathrm{~d})$ for bronchopulmonary dysplasia. Enteral feeding was generally introduced on the second postnatal day with preterm formula (containing $75 \mathrm{mg}$ calcium, $48 \mathrm{mg}$ phosphorus, $8 \mathrm{mg}$ magnesium per $100 \mathrm{~mL}$ ) or fortified human milk (calcium, phosphorus, magnesium contents were $81 \mathrm{mg}, 49 \mathrm{mg}, 5.5 \mathrm{mg}$ per $100 \mathrm{~mL}$, respectively). Supplementary parenteral nutrition was given for about $15 \mathrm{~d}$ in both groups (bone disease group 15 d, no bone disease group 14 d). Full enteral nutrition $(150 \mathrm{~mL} / \mathrm{kg} / \mathrm{d})$ was generally achieved by the 16 th postnatal day. All infants received a supplement of $400 \mathrm{IU} / \mathrm{d}$ vitamin D (cholecalciferol) starting from the 7th day of life.

At the ages of $1,2,3,6$, and $12 \mathrm{mo}$, the following analyses were performed. Serum and urine calcium were measured by colorimetric method (Architect analyzer, Abbott Laboratories, Abbott Park, IL). Serum and urine inorganic phosphorus were detected by the ammonium-phosphomolibdate-UV method (Architect analyzer, Abbott Laboratories). Alkaline phosphatase and serum magnesium were analyzed by standard DGKCh (Deutsche Gesellschaft für Klinische Chemie) method (Architect analyzer) and flame atom absorption spectrophotometry (Varian Spectrum AA-20 analyzer, Varian Inc., Mulgrave, Victoria, Australia), respectively. PTH was determined by luminescence strengthened enzyme immunoassay and osteocalcin by chemiluminescence enzyme immunoassay (both with Immulite analyzer, Diagnostics Products, Los Angeles, CA, USA). At the same time, bone resorption was assessed by the measurement of urinary pyridinium crosslink by chemiluminescence enzyme immunoassay (Immulite analyzer, Diagnostics Products) corrected for creatinine concentration, expressed as $\mathrm{nmol} / \mathrm{mmol}$ creatinine. Urinary creatinine was measured by a kinetic Jaffe method (Abbott Laboratories).

The intra- and interassay coefficients of variation were as follows: serum calcium $0.7 \%$ and $0.8 \%$, urine calcium $0.7 \%$ and $0.2 \%$, serum inorganic phosphorus $0.5 \%$ and $0.8 \%$, urine inorganic phosphorus $1.1 \%$ and $0.7 \%$, alkaline phosphatase $0.4 \%$ and $2.1 \%$, magnesium $2.0 \%$ and $3.6 \%$, PTH $3.9 \%$ and $5.4 \%$, osteocalcin $2.8 \%$ and $3.5 \%$, urinary pyridinium crosslink $15.0 \%$ and $4.7 \%$, and creatinine $1.1 \%$ and $0.5 \%$.

Blood and urine samples were collected between 0700 and $1000 \mathrm{~h}$. For infants with bone disease, follow-up x-rays of the chest and wrist (together with the distal portions of associated long bones) were obtained at the ages of 2 and 6 mo. Radiographic diagnoses were based on the Koo score (13).

Genetic analysis for the polymorphisms of the VDR, ER, and COLIA1 genes was performed using genomic DNA isolated from EDTA-treated peripheral blood.

To determine VDR polymorphisms, PCR was used to amplify the $740 \mathrm{bp}$ region of exon 9, known to contain a constant and a polymorphic TaqI endonuclease site (14). PCR products were digested with TaqI endonuclease and resolved by agarose gel electrophoresis. Restriction fragment length polymorphisms (RFLP) were coded as follows: TT $=$ homozygotes, absence of the TaqI restriction fragment sites; $\mathrm{Tt}=$ heterozygotes; $\mathrm{tt}=$ homozygotes, and presence of the polymorphic size.

To identify ER dinucleotide repeat polymorphisms, PCR was performed using oligonucleotide primers designed to amplify the polymorphic (TA) repeat of the human ER gene at 1174 bp upstream (15). The number of (TA) repeats in each amplified products was determined by the comparison of the length of PCR products to the sequence ladder of control DNA.

COLIA1 gene genotype was determined after restriction of endonuclease digestion with BALI (7). The genotype was classified as follows: $\mathrm{CC}=$ homozygotes, absence of the restriction site resulting in one fragment $255 \mathrm{bp}$; $\mathrm{Cc}=$ heterozygotes exhibiting fragments of $255 \mathrm{bp}, 236 \mathrm{bp}$, and $19 \mathrm{bp}$; and $\mathrm{cc}=$ homozygotes, presence of the restriction site results in two fragments of $236 \mathrm{bp}$ and $19 \mathrm{bp}$.

Ethics The study was approved by the Regional Research Ethics Committee of the Medical School of Pécs. Written consent was obtained from parents.

Statistical analyses. Unpaired $t$ test (for birth weight and height, CRIB score, parity, and the duration of hospitalization) and $\chi^{2}$ test (for gender, Apgar score at 1 and $5 \mathrm{~min}$ ) were used to determine differences in demographic and clinical characteristics between infants with and without bone disease. The $t$ test was applied only after normal distribution of the data were confirmed by Kolgomorov-Smirnov test and homoscedasity verified by $\mathrm{F}$ test.
Multivariate analyses were carried out by logistic regression analysis to investigate the influence of genetic polymorphisms and clinical risk factors on development of bone disease. Forward stepwise logistic regression analysis was applied to determine the set of independent clinical and genetic risk factors.

Statistical analysis was performed by Statistical Package for Social Sciences (SPSS 12.0 for Windows; SPSS Inc., Chicago, IL). Demographic, clinical data, and biochemical parameters are expressed as mean values \pm SEM. Values of $p<0.05$ (two-tailed) were considered statistically significant.

\section{RESULTS}

Bone disease was diagnosed in 20 out of 65 VLBW infants $(30.8 \%)$ based on serum alkaline phosphatase, osteocalcin, PTH, urinary pyridinium crosslink, and calcium excretion. Radiologic signs were present in all cases except for two twin pairs, who all had unambiguously abnormal biochemical parameters. Radiologic abnormalities were generally noted in the second month postnatally; improvement in radiologic signs was generally observed at the age of 6 mo. Radiologic abnormalities were grade 1 or 2 on the Koo score (13). No infants had bone fractures.

At the age of $1 \mathrm{mo}$, infants with bone disease had significantly lower serum phosphorus values $(2.08 \pm 0.06$ versus $2.29 \pm 0.06 \mathrm{mM}, p<0.05)$ and significantly higher alkaline phosphatase levels $(909 \pm 59$ versus $677 \pm 30 \mathrm{IU} / \mathrm{L}, p<$ $0.001)$ than infants without bone disease. Alkaline phosphatase values remained high during the entire study period (2 mo: $1023 \pm 69$ versus $718 \pm 26 \mathrm{IU} / \mathrm{L}, p<0.001 ; 3$ mo: 1135 \pm 78 versus $825 \pm 33 \mathrm{IU} / \mathrm{L}, p<0.001 ; 6$ mo: $1226 \pm 64$ versus $830 \pm 32 \mathrm{IU} / \mathrm{L}, p<0.001 ; 12 \mathrm{mo}: 948 \pm 58 \mathrm{IU} / \mathrm{L}$ versus $697 \pm 28 \mathrm{IU} / \mathrm{L}, p<0.001$ ) (Fig. 1). Osteocalcin levels, also markers of bone formation, were significantly higher at ages of $2,3,6$, and 12 mo ( 2 mo: $29.6 \pm 3.0$ versus $21.3 \pm$ $1.8 \mathrm{ng} / \mathrm{mL}, p<0.01 ; 3$ mo: $32.2 \pm 3.6$ versus $19.7 \pm 1.5$ $\mathrm{ng} / \mathrm{mL}, p<0.001 ; 6$ mo: $35.2 \pm 4.4$ versus $16.3 \pm 1.3 \mathrm{ng} / \mathrm{mL}$, $p<0.001 ; 12$ mo: $18.8 \pm 3.3$ versus $12.9 \pm 1.0 \mathrm{ng} / \mathrm{mL}, p<$ 0.01) (Fig. 2). The differences in the urinary pyridinoline crosslink levels, marker of bone resorption, were the most striking at ages of 2,3 , and 6 mo $(68.7 \pm 5.8$ versus $48.7 \pm$ $1.9 \mathrm{nmol} / \mathrm{mmol}$ creatinine, $p<0.001 ; 64.08 \pm 4.5$ versus 44.6

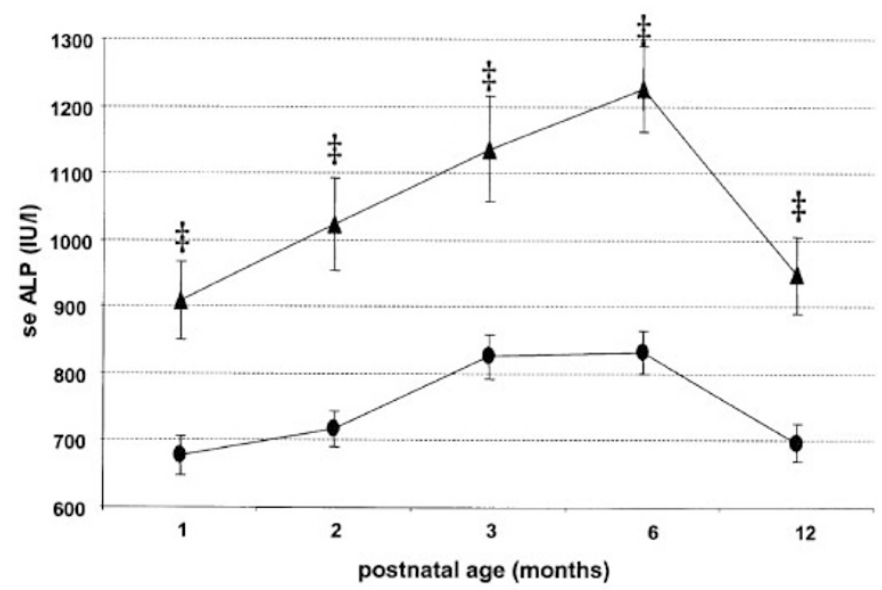

Figure 1. Postnatal changes in serum alkaline phosphatase (se ALP) level. Values are means \pm SEM; $\ddagger p<0.001$ comparing infants with and without bone disease. Bone disease $(\boldsymbol{\Lambda})$, no bone disease $(\boldsymbol{\bullet})$. 


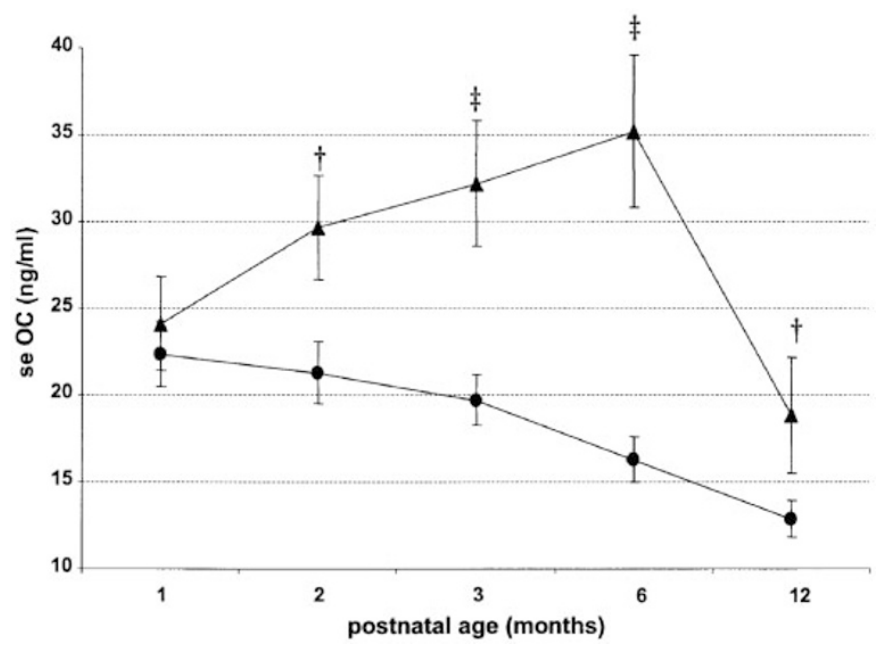

Figure 2. Postnatal changes in serum osteocalcin (se $O C$ ) level. Values are means $\pm \mathrm{SEM} ; \dagger p<0.01, \ddagger p<0.001$ comparing infants with and without bone disease. Bone disease $(\boldsymbol{\Lambda})$, no bone disease $(\mathbf{\bullet})$.

$\pm 1.6 \mathrm{nmol} / \mathrm{mmol}$ creatinine, $p<0.001 ; 58.1 \pm 3.8$ versus $38.6 \pm 1.5, p<0.001$ ) (Fig. 3). We detected significantly higher urinary calcium excretion (expressed as $\mathrm{mmol} / \mathrm{mmol}$ creatinine) at ages of $2,3,6$, and 12 mo in infants with bone disease $(2.7 \pm 0.5$ versus $1.7 \pm 0.2 \mathrm{mmol} / \mathrm{mmol}$ creatinine, $p<0.05 ; 2.9 \pm 0.4$ versus $1.3 \pm 0.1 \mathrm{mmol} / \mathrm{mmol}$ creatinine, $p<0.001 ; 2.5 \pm 0.3$ versus $1.1 \pm 0.1 \mathrm{mmol} / \mathrm{mmol}$ creatinine, $p<0.01 ; 1.3 \pm 0.2$ versus $0.8 \pm 0.1 \mathrm{mmol} / \mathrm{mmol}$ creatinine, $p<0.01$ ) (Fig. 4). PTH levels were significantly higher in the bone disease group at ages of $6(3.1 \pm 0.6$ versus $1.5 \pm 0.1 \mathrm{mM}, p<0.001)$ and $12 \mathrm{mo}(2.3 \pm 0.3$ versus 1.5 $\pm 0.1 \mathrm{mM}, p<0.01)$. There was no significant difference between groups in serum calcium and magnesium levels.

Clinical risk factors. Investigating the influence of gestational age, birth weight, birth height, gender, CRIB score (a marker of illness severity), duration of hospitalization, $1 \mathrm{~min}$ and 5 min Apgar scores, and maternal parity as possible clinical risk factors, only male gender $(p<0.001)$, high CRIB score $(p<0.05)$ and high maternal parity $(p<0.05)$ were found to correlate with bone disease (Table 1). In a multivar-

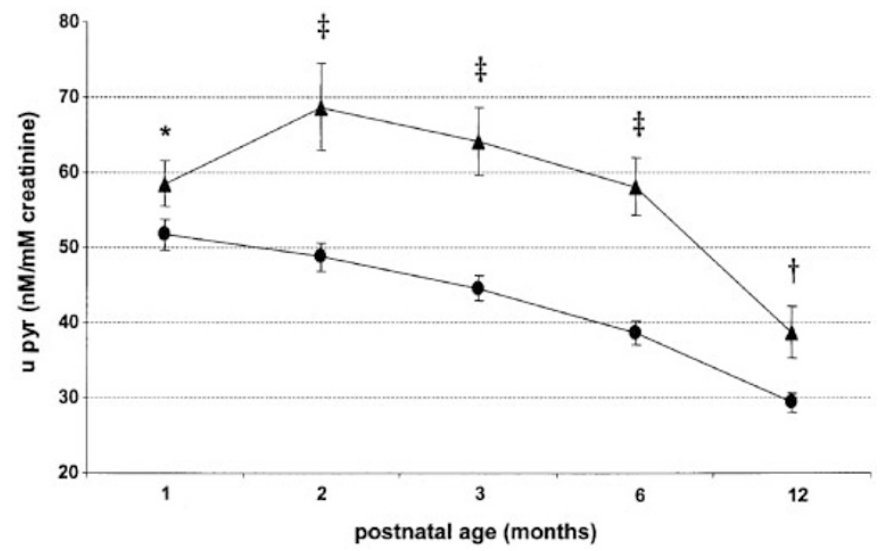

Figure 3. Postnatal changes in urinary pyridinoline crosslink ( $u$ pyr) level/ mmol creatinine. Values are means $\pm \mathrm{SEM} ;{ }^{*} p<0.05, \dagger p<0.01, \ddagger p<$ 0.001 comparing infants with and without bone disease. Bone disease $(\boldsymbol{\Lambda})$, no bone disease ( $)$.

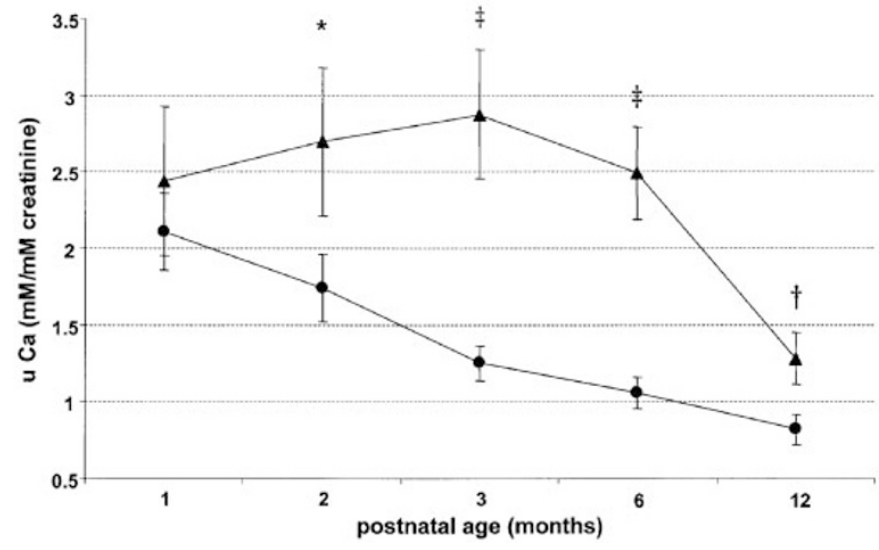

Figure 4. Postnatal changes in urinary calcium excretion $(u \mathrm{Ca})$ level $/ \mathrm{mmol}$ creatinine. Values are means $\pm \mathrm{SEM} ; * p<0.05, \dagger p<0.01, \ddagger p<0.001$ comparing infants with and without bone disease. Bone disease $(\boldsymbol{\Lambda})$, no bone disease $(\bullet)$

iate analysis, only male gender was found to be a significant independent risk factor [odds ratio (OR): $0.04,95 \%$ confidence interval (CI): 0.01-0.26, $p<0.001$ ) (Table 1 ).

Genetic factors. The genotypic distribution of $(\mathrm{TA})_{\mathrm{n}}$ dinucleotide repeat polymorphism in the first exon upstream of the ESR1 gene, the TaqI polymorphism in the exon of the VDR gene as well as G-to-T polymorphism in the first intron of the COLIA1 gene in 65 VLBW infants are shown in Table 2. Examining the distribution of the VDR gene and COLIA1 gene polymorphisms separately, we could not observe any significant difference (Table 2). However, a statistically significant correlation between $(\mathrm{TA})_{\mathrm{n}}$ repeat allelic variant and bone disease was observed. According to the distribution pattern of $(\mathrm{TA})_{\mathrm{n}}$ alleles, we divided the infants into three groups: i) group $\mathrm{HoH}$, including homozygous alleles with a high number of $(\mathrm{TA})_{\mathrm{n}}$ repeats $\left[(\mathrm{TA})_{\mathrm{n}}>18\right]$; ii) group HeHL, including heterozygous alleles with a high and a low number of (TA) $)_{n}$ repeats; and iii) group HoL, including homozygous alleles with low numbers of $(\mathrm{TA})_{\mathrm{n}}$ repeats $\left[(\mathrm{TA})_{\mathrm{n}}<19\right]$. Infants in the HoL group suffered significantly more often from bone disease $(p<0.01)$. In contrast, infants with a high number of $(\mathrm{TA})_{\mathrm{n}}$ repeats in both alleles were protected against

Table 1. Patients' characteristics influence on bone disease occurrence

\begin{tabular}{lcc}
\hline & $\begin{array}{c}\text { Infants with } \\
\text { bone disease } \\
(n=20)\end{array}$ & $\begin{array}{c}\text { Infants without } \\
\text { bone disease } \\
(n=45)\end{array}$ \\
\hline Gestational age (wk) & $28.3 \pm 0.5$ & $29.1 \pm 0.4$ \\
Birth weight $(\mathrm{g})$ & $1102 \pm 67$ & $1124 \pm 33$ \\
Birth height $(\mathrm{cm})$ & $36.9 \pm 0.7$ & $37.0 \pm 0.6$ \\
Gender (male) & $18(90 \%)$ & $6(35 \%) \dagger$ \\
CRIB score & $7.4 \pm 0.7$ & $5.6 \pm 0.6^{*}$ \\
1 min Apgar score & $7 / 4-9$ & $8 / 1-9$ \\
5 min Apgar score & $9 / 6-10$ & $9 / 4-10$ \\
Parity & $4.6 \pm 0.5$ & $3.5 \pm 0.3^{*}$ \\
Duration of & $77 \pm 9$ & $64 \pm 5$ \\
$\quad$ hospitalization (d) & & \\
\hline
\end{tabular}

Data are expressed in means \pm SEM or percentage. $* p<0.05$ (univariate analysis), $\dagger p<0.001$ (univariate and multivariate analysis) when comparing infants with and without bone disease. 
Table 2. Genotypic distributions in VLBW infants with and without bone disease $(n=65)$

\begin{tabular}{|c|c|c|c|}
\hline Gene & Polymorphism & $\begin{array}{l}\text { Infants with } \\
\text { bone disease } \\
\quad(n=20)\end{array}$ & $\begin{array}{l}\text { Infants without } \\
\text { bone disease } \\
(n=45)\end{array}$ \\
\hline \multirow[t]{3}{*}{ VDR } & $\mathrm{Tt}$ & $9(45 \%)$ & $29(65 \%)$ \\
\hline & TT & $9(45 \%)$ & $14(31 \%)$ \\
\hline & $\mathrm{tt}$ & $2(10 \%)$ & $2(4 \%)$ \\
\hline \multirow{3}{*}{ COLIA1 } & $\mathrm{Cc}$ & $9(45 \%)$ & $11(24 \%)$ \\
\hline & $\mathrm{CC}$ & $10(50 \%)$ & $31(69 \%)$ \\
\hline & $\mathrm{cc}$ & $1(5 \%)$ & $3(7 \%)$ \\
\hline \multirow[t]{2}{*}{ ESR1 } & $(\mathrm{TA})_{\mathrm{n}}$ repeat numbers: $<19$ & $15(75 \%)$ & $14(31 \%)^{*}$ \\
\hline & $(\mathrm{TA})_{\mathrm{n}}$ repeat numbers: $>18$ & $5(25 \%)$ & $31(69 \%)^{*}$ \\
\hline
\end{tabular}

$\mathrm{Tt}, \mathrm{TT}, \mathrm{tt}=\mathrm{RFLP}$ of VDR gene; $\mathrm{Cc}, \mathrm{CC}, \mathrm{cc}=\mathrm{RFLP}$ of COLIA1 gene. $* p<0.05$ when comparing infants with and without bone disease.

bone disorder $(p<0.01)$ (Table 3). Using a logistic regression forward stepwise analysis, this correlation between bone disease and HoH group members was shown to remain significant $(p=0.006)$ (Table 4).

To analyze the combined influence of polymorphisms in these three candidate genes in determining bone disease, we performed a logistic regression analysis. The genotype combinations found most commonly are listed in Table 5 . We observed significant interaction $(p<0.05)$ between VDR and COLIA1 genotype effects. The common occurrence of the heterozygote Tt RFLP of the VDR gene and CC polymorphism of the COLIA1 gene was a protective factor with regard to developing bone disease (OR: $0.2,95 \%$ CI: 0.06-0.69) (Table 5). Logistic regression forward stepwise analysis revealed this interaction as an independent factor in developing bone disease.

The association of the above-mentioned Tt or CC polymorphism with homozygous carriers of a high number of (TA) repeats $(\mathrm{HoH}$ allele) was found to be overrepresented in infants without bone disease $(p<0.05)$. In spite of this, the association of Cc polymorphism with homozygous carriers of a low numbers of $(\mathrm{TA})_{\mathrm{n}}$ repeats (HoL allele) was correlated with bone disease $(p=0.01)$ (Table 5).

Investigating clinical and genetic risk factors using multivariate analysis, male gender and the $(\mathrm{TA})_{\mathrm{n}}$ polymorphism of the ER gene remained as risk factors $(p<0.01)$ (Table 6).

\section{DISCUSSION}

With a better survival rate of VLBW infants, the importance of investigating the organic and functional abnormalities of the children surviving has been increasing. The analysis of

Table 3. Association between ER $\alpha$ gene dinucleotide repeat polymorphism and bone disease of preterm birth

\begin{tabular}{lcc}
\hline Genotype & OR & $95 \%$ CI \\
\hline HoH & & 1 (reference)* \\
HeHL & 6 & $0.68-52.90$ \\
HoL & 6 & $1.77-20.31^{*}$ \\
\hline
\end{tabular}

Groups: $\mathrm{HoH}$, homozygous allel of high number repeats $\left[(\mathrm{TA})_{\mathrm{n}}>18\right.$ ]; HeHL, heterozygous allel of low and high number of repeats; HoL, homozygous allel of low number of repeats [(TA $\left.)_{n}<19\right]$. Data are expressed as odds ratios and $95 \%$ confidence intervals. $* p<0.01$ when comparing infants with and without bone disease.
Table 4. Genetic and clinical risk factors for bone disease according to the result of forward stepwise logistic regression analysis

\begin{tabular}{lccc}
\hline \multicolumn{1}{c}{ Risk factor } & OR & $95 \%$ CI & $p$ Value* \\
\hline Gender & 0.04 & $0.01-0.31$ & 0.002 \\
Gestational age & 0.45 & $0.24-0.86$ & 0.015 \\
HoH allele & 0.02 & $0.01-0.31$ & 0.006 \\
Interaction: Tt-CC & 0.03 & $0.01-0.43$ & 0.009 \\
\hline
\end{tabular}

Groups: $\mathrm{HoH}$, homozygous allel of high number repeats [(TA) $>18$ ]; $\mathrm{Tt}$, RFLP of VDR gene, CC, RFLP of collagen $\mathrm{I} \alpha 1$ gene; Interaction Tt-CC, interlocus action between VDR and COLIA1 gene; data are expressed as odds ratios and $95 \%$ confidence intervals. $*$ Significance when comparing infants with and without bone disease.

risk factors for one of these abnormalities, bone disease, is of special significance for two reasons: 1) osteoporosis in later life is a public health challenge, and 2) a better understanding of the natural course of bone abnormalities would result in preventive measurements and provide a base for accurate prognosis.

This study was conducted primarily to investigate the influence of genetic factors on bone disease in prematurely born infants. The results of our study indicate that bone disease in preterm infants is associated with certain genetic factors, namely the (TA) $)_{n}$ polymorphism of the $\operatorname{ER} \alpha$ gene and the locus interaction between VDR and COLIA1 genes, which may influence the development of bone disease.

As others have, we used alteration of biochemical markers, for bone formation (ALP, osteocalcin) and bone resorption (urinary pyridinoline crosslink, calcium excretion) to assess increased bone turnover $(4,16-18)$. In addition, radiologic signs were used, with recognition that they are not visible until bone mineralization is reduced by at least $20 \%$ (19). In our study, 20 infants $(30.8 \%)$ were diagnosed with bone disease.

Table 5. Interlocus actions between the main candidate genes of osteoporosis (listed according to the frequency of occurrence)

\begin{tabular}{lccc}
\hline Interaction & No. & OR & $\begin{array}{c}\text { Regression } \\
\text { coefficient }\end{array}$ \\
\hline Tt-CC & 29 & 0.20 & $-1.609^{*}$ \\
CC-HoH & 24 & 0.20 & $-1.601^{*}$ \\
Tt-HoH & 18 & 0.09 & $-2.445^{*}$ \\
CC-HoL & 17 & 1.88 & 0.634 \\
Tt-HoL & 17 & 1.88 & 0.634 \\
TT-HoH & 11 & 0.77 & -0.258 \\
TT-CC & 9 & 2.16 & 0.773 \\
Tt-Cc & 8 & 3.42 & 1.229 \\
Cc-HoH & 8 & 0.28 & 2.493 \\
Cc-HoL & 8 & 9.21 & $2.221 \dagger$ \\
TT-HoL & 8 & 4.67 & 21.943 \\
TT-Cc & 4 & 1.41 & 6.583 \\
Cc-HeHL & 4 & 2.39 & 0.871 \\
TT-cc & 3 & 0.74 & -0.305 \\
cc-HoH & 3 & 1.13 & 0.124 \\
Tt-HeHL & 3 & 1.13 & 0.124 \\
tt-Cc & 1 & 1.13 & 0.124 \\
\hline
\end{tabular}

Groups: Tt, TT, $t \mathrm{t}=$ RFLP of VDR gene; $\mathrm{Cc}, \mathrm{CC}, \mathrm{cc}=\mathrm{RFLP}$ of the COLIA1 gene; $\mathrm{HoH}=$ homozygous allel of high number repeats $\left[(\mathrm{TA})_{\mathrm{n}}>\right.$ 18]; HoL $=$ homozygous allel of low number repeats [(TA $)_{\mathrm{n}}<19$ ]; $\mathrm{HeHL}=$ heterozygous allel of high and low number repeats. Data are expressed as odds ratios and regression coefficients. ${ }^{*} p<0.05, \dagger p=0.01$ for comparison between infants with and without bone disease. 
Table 6. Multivariate analysis of clinical and genetic risk factors for bone disease

\begin{tabular}{lcc}
\hline \multicolumn{1}{c}{ Risk factor } & OR & $\begin{array}{c}\text { Regression } \\
\text { coefficient }\end{array}$ \\
\hline Birth weight & 1.007 & 0.007 \\
Birth height & 0.813 & -0.207 \\
Gender & 0.019 & $-4.028 \dagger$ \\
Gestational age & 0.636 & -0.453 \\
CRIB score & 1.146 & 0.136 \\
Duration of hospitalization & 1.037 & 0.036 \\
VDR polymorphism $(\mathrm{TT} / \mathrm{Tt})$ & 6.329 & 1.845 \\
VDR polymorphism $(\mathrm{tt} / \mathrm{Tt})$ & 3.455 & 1.234 \\
COLIA1 polymorphism $(\mathrm{CC} / \mathrm{Cc})$ & 0.489 & -0.716 \\
COLIA1 polymorphism $(\mathrm{cc} / \mathrm{Cc})$ & 0.647 & -0.435 \\
ER polymorphism $(\mathrm{HeHL} / \mathrm{HoH})$ & 194.601 & $5.271^{*}$ \\
ER polymorphism $(\mathrm{HoL} / \mathrm{HoH})$ & 37.21 & $3.616 \dagger$ \\
\hline
\end{tabular}

$\mathrm{TT}, \mathrm{Tt}, \mathrm{tt}=\mathrm{RFLP}$ of VDR gene; $\mathrm{CC}, \mathrm{Cc}, \mathrm{cc}=\mathrm{RFLP}$ of COLIA1 (collagen $\mathrm{I} \alpha 1$ receptor) gene; $\mathrm{HeHL}, \mathrm{HoH}, \mathrm{HoL}=(\mathrm{TA})_{\mathrm{n}}$ repeats of ER gene. Data are expressed as odds ratios and regression coefficients. ${ }^{*} p<0.05, \dagger p<0.01$ for comparison between infants with and without bone disease.

This rate is in agreement with the reported incidence of bone disease in VLBW infants $(20,21)$.

Due to the diverse gestational ages at birth, infants with different degrees of maturation were studied at the same time intervals. It might have been preferable to study the subjects at corrected postnatal ages. However, using univariate and multivariate analysis, no significant difference in gestational age could be detected between infants with and without bone disease (Table 1); therefore, we suggest that gestational age did not significantly influence our results.

As far as we know, this is the first study in premature infants showing that subjects with low numbers of (TA) repeats suffer more often from osteopenia and osteoporosis and have higher levels of urinary pyridinium crosslink levels than those with other genotypes. Similar observations have been made in adults $(15,22,23)$. The influence of the variability of the laboratory method regarding pyridinium crosslink excretion cannot be completely excluded because of the intraassay variability of $15 \%$. With regard to the fact that the pyridinium crosslink findings are in concordance with the consequences drawn from other bone resorption and bone formation results, we think that this biochemical parameter reflects accurately bone resorption. The molecular mechanisms responsible for our observation are not yet known. $(\mathrm{TA})_{\mathrm{n}}$ polymorphism may directly affect gene expression through transcription regulation or may be linked with other exonic polymorphisms regulating ESR 1 protein function directly. At least three different promoters have been identified in the ESR1 gene $(24,25)$. The different $(T A)_{n}$ dinucleotide region lies between promoter $\mathrm{A}$ and $\mathrm{B}$. It is possible that the different length of this polymorphism might have physiologic relevance by affecting promoter usage.

Furthermore, our results indicate that boys are more likely to be affected with bone disease than girls. This may be related to the observation that the estrogen level in VLBW preterm boys is lower than in girls $(26,27)$. In adults, common allelic variants of ESR1 gene are related to variation in responsiveness to estrogen. It has been proposed that compensatory hyperestrogenism can regulate this relative resistance and may be disturbed in menopause, leading to osteoporosis (28). Thus, lower estrogen levels may predispose boys to bone disorders. Further studies are needed to examine estrogen levels in VLBW infants in association with ESR1 polymorphisms.

The locus interaction between VDR and COLIA1 genes observed by logistic regression analysis is worthy of discussion. Few studies have addressed the interaction between the different osteoporosis candidate genes. An interaction between VDR and COLIA1 gene as well as an association between VDR and ESR1 gene may play a role at least in print in the pathogenesis of fractures $(10,29)$. Examining the VDR and COLIA1 genotypes separately, we found no significant difference in genotype distribution between infants with and without bone disease.

The study of a larger number of infants would increase the prospect of finding further associations between genotype and bone disorder in premature infants.

However, we observed a significant association between VDR and COLIA1 genotype. The common occurrence of CC genotype (absence of the thymine allele) of the COLIA1 gene and Tt genotype (heterozygotes) of the VDR gene protected the infants from developing bone disease. VDR is a steroid transcription factor and regulates the expression of the COLIA1 gene (30,31). Genetic variations in the VDR gene can be expected to influence the effects of COLIA1 gene polymorphisms in regard to bone disease.

In conclusion, this study shows that the development of bone disease in VLBW infants is related to clinical factors such as gender and gestational age.

We have demonstrated an association in VLBW infants between bone disease and certain genetic factors. The (TA) polymorphism of the ER $\alpha$ gene determines the development of bone disease. The locus interaction between the VDR and COLIA1 genes may play an important part in the protection of preterm infants from bone disease.

However, it must be kept in mind that the small sample size of this study limits the statistical power of our observations. Further investigations are needed to look for additional associations between genetic polymorphisms and bone disease in premature infants.

Acknowledgments. The authors thank János Sándor, M.D., Ph.D., and Gábor Biró, Ph.D., for expert technical assistance in the statistical analyses. We also thank Anna Erdélyi for genotyping.

\section{REFERENCES}

1. Miller ME 2003 The bone disease of preterm birth: a biomechanical perspective Pediatr Res 53:10-15

2. Rauch F, Schoenau E 2002 Skeletal development in premature infants: a review of bone physiology beyond nutritional aspects. Arch Dis Child Fetal Neonatal Ed 86:F82-F85

3. Litmanovitz I, Dolfin T, Friedland O, Arnon S, Regev R, Shainkin-Kestenbaum R, Lis M, Eliakim A 2003 Early physical activity intervention prevents decrease of bone strength in very low birth weight infants. Pediatrics 112:15-19

4. Aly H, Moustafa MF, Amer HA, Hassanein S, Keeves C, Patel K 2005 Gestational age, sex and maternal parity correlate with bone turnover in premature infants. Pediatr Res 57:708-711

5. Pocock NA, Eisman JA, Hopper JL, Yeates MG, Eberl PN 1987 Genetic determinants of bone mass in adults. A twin study. J Clin Invest 80:706-710

6. Cooper GS, Umbach DM 1996 Are vitamin D receptor polymorphisms associated with bone mineral density? A meta-analysis. J Bone Miner Res 11:1841-1849 
7. Grant SF, Reid DM, Blake G, Herd R, Fogelman I, Ralston SH 1996 Reduced bone density and osteoporosis associated with a polymorphic Sp1 binding site in the collagen type I $\alpha 1$ gene. Nat Genet 14:203-205

8. Langdahl BL, Lokke E, Carstens M, Stenkjaer LL, Eriksen EF 2000 A TA repeat polymorphism in the estrogen receptor gene is associated with osteoporotic fractures but polymorphisms in the first exon and intron are not. J Bone Miner Res 15:22222230

9. Uitterlinden AG, Weel AE, Burger H, Fang Y, Van Duijn CM, Hofman A, van Leeuwen, JP Pols HA 2001 Interaction between the vitamin D receptor gene and collagen type $\mathrm{I} \alpha 1$ gene in susceptibility for fracture. J Bone Miner Res 16:379-385

10. Colin EM, Uitterlinden AG, Meurs JB, Bergink AP, van de Klift, M Fang Z, Arp P, Hofman A, van Leeuwen JP, Pols HA 2003 Interaction between vitamin D receptor genotype and estrogen receptor $\alpha$ genotype influences vertebral fracture risk. J Clin Endocrinol Metab 88:3777-3784

11. Backström MC, Mahonen A, Ala-Houhala M, Sievänen H, Mäenpää P, Koivisto AM, Olkuu A, Mäki R, Mäki M 2001 Genetic determinants of bone mineral content in premature infants. Arch Dis Child Fetal Neonatal Ed 85:F214-F216

12. Ballard JL, Khoury CJ, Wedig K, Wang L, Eilers-Walsman BL, Lipp R 1991 New Ballard score, expanded to include extremely premature infants. J Pediatr 119:417423

13. Koo WW, Gupta JM, Nayanar VV, Wilkinson M, Posen S 1982 Skeletal changes in preterm infants. Arch Dis Child 57:447-452

14. Spector TD, Keen RW, Arden NK, Morrison NA, Major PJ, Nguyen TV, Kelly PJ, Baker JR, Sambrook PN, Lanchbury JS, Eisman JA 1995 Influence of vitamin D receptor genotype on bone mineral density in postmenopausal women: a twin study in Britain. BMJ 310:1357-1360

15. Sano M, Inoue S, Hosoi T, Ouchi Y, Emi M, Orimo H 1995 Association of estrogen receptor dinucleotide repeat polymorphism with osteoporosis. Biochem Biophys Res Commun 217:378-383

16. Lapillonne A, Picaud JC, Glorieux FH, Salle BL 2000 Bone turnover assessment in infants. Acta Paediatr 89:772-774

17. Crofton PM, Shrivastava A, Wade JC, Stephen R, Kelnar CJ, Lyon AJ, McIntosh N 1999 Bone and collagen markers in preterm infants: relationship with growth and bone mineral content over the first 10 weeks of life. Pediatr Res 46:581-587

18. Shiff Y, Eliakim A, Shainkin-Kestenbaum R, Arnon S, Lis M, Dolfin T 2001 Measurements of bone turnover in premature infants. J Pediatr Endocrinol Metab 14:389-395

19. Ardran GM 1951 Bone destruction not demonstrable by radiography. Br J Radiol 24:107-109
20. Koo WW, Oestreich AE, Sherman R, Tsang RC, Steichen JJ, Young LW 1985 Osteopenia, rickets and fractures in preterm infants. Am J Dis Child 139:10451046

21. Koo WW, Shermann R, Succop P, Krug-Wispe S, Tsang RC, Steichen JJ 1989 Fractures and rickets in very low birthweight infants: conservative management and outcome. J Pediatr Orthop 9:326-330

22. Kunnas TA, Holmberg-Martilla D, Karhunen PJ 1999 Analysis of estrogen receptor dinucleotide polymorphism by capillary gel electrophoresis with a population genetic study in 180 Finns. Hum Hered 49:142-145

23. Becherini L, Gennari L, Masi L, Mansani R, Massart F, Morelli A, Falchetti A, Gonnelli S, Fiorelli G, Tanini A, Brandi ML 2000 Evidence of a linkage disequilibrium between polymorphisms in the human estrogen receptor alpha gene and their relationship to bone mass variation in postmenopausal Italian women. Hum $\mathrm{Mol}$ Genet 9:2043-2050

24. Donaghue C, Westley BR, May FE 1999 Selective promotor usage of the human estrogen receptor $\alpha$ gene and its regulation by estrogen. J Mol Endocrinol 13:19341950

25. Van Meurs JB, Schuit SC, Weel AE, van der Klift M, Bergink AP, Arp PP, Colin AM, Fang Y, Hofman A, van Duijn CM, van Leeuwen, JP, Pols HA, Uitterlinden AG 2003 Association of 5'estrogen receptor alpha gene polymorphisms with bone mineral density, vertebral bone area and fracture risk. Hum Mol Genet 12:17451754

26. Dötsch J, Dörr HG, Wildt L 2001 Exposure to endogenous estrogens during lifetime. In: Metzler M (ed) The Handbook of Environmental Chemistry. Springer-Verlag, Berlin, pp 81-99

27. Bidlingmaier F, Strom TM, Dorr HG, Eisenmenger W, Knorr D 1987 Estrone and estradiol concentrations in human ovaries, testes, and adrenals during the first two years of life. J Clin Endocrinol Metab 65:862-867

28. Speroff L 2000 A clinical understanding of the estrogen receptor. Ann N Y Acad Sci 900:26-39

29. Uitterlinden AG, Burger H, Huang Q, Yue F, McGuigan FE, Grant SF, Hofman A, van Leeuwen, JP, Pols HA, Ralston SH 1998 Relation of alleles of the collagen type I $\alpha 1$ gene to bone density and the risk of osteoporotic fractures in postmenopausal women. N Engl J Med 338:1016-1021

30. Slack JL, DeAnn JL, Bornstein P 1993 Regulation of expression of the type collagen genes. Am J Med Genet 45:140-151

31. Pavlin D, Bedalov A, Kronenberg M, Kream BE, Rowe DW, Smith CL, Pike JW, Lichter AC 1994 Analysis of regulatory regions in the COLIAI gene responsible for 1,25-dihydroxyvitamin D3-mediated transcriptional repression in osteoblastic cells. J Cell Biochem 56:490-501 